\title{
Amyloidosis complicated by intractable postural hypotension
}

\author{
G. M. YUILL* \\ M.B. Ch.B., M.R.C.P., B.Sc. \\ University Hospital of South Manchester, Manchester M20 8LR
}

\begin{abstract}
Summary
A patient is described in whom the nephrotic syndrome caused by amyloidosis was complicated by intractable postural hypotension. An account is given of his treatment with a combination of monoamine oxidase inhibitors and sympathomimetic pressor agents, after a failure of conventional therapy.
\end{abstract}

\section{Introduction}

The presence of postural hypotension complicating amyloid disease has been well documented. Kyle, Kottke \& Schirger (1966) reviewed the case records of 138 patients in the Mayo Clinic in whom the diagnosis had been confirmed by biopsy or necropsy. In eleven $(9 \%)$ of these cases postural hypotension was found. The following signs and symptoms were attributed to an amyloid autonomic neuropathy: syncope in eight cases, peripheral neuropathy in two, impotence in two, and dyshidrosis in them all. Munsat collected sixteen cases of polyneuropathy due to amyloid from the literature and to these added three cases of his own. These patients presented with chronic sensory and motor neuropathy, gastrointestinal symptoms, hoarseness, impotence, orthostatic hypotension, dyshidrosis and trophic ulcers.

It was suggested in these papers that postural hypotension is due to the presence of amyloid interfering with autonomic nervous function. Bannister, Ardill \& Fentem (1967) undertook detailed physiological studies in patients with idiopathic postural hypotension and concluded that the cause of the hypotension was an impaired reflex vasoconstriction in the resistance and capacity vessels. Indirect evidence possibly indicating diminished sympathetic nervous activity in these cases comes from biochemical studies. McC. Goodall, Harlan \& Alton(1968) showed in three patients with idiopathic postural hypotension that there was a diminution in production of noradrenaline and its principle metabolites, and they suggested that this and the postural hypotension were a consequence of a defect in the neurogenic

* Present address: University Department of Neurology, Manchester Royal Infirmary, Manchester M13 9WL. structures involved in the biosynthesis of noradrenaline. In one of their cases necropsy study showed degenerative changes in the sympathetic ganglia. Luft \& Von Euler (1955) and Diamond, Murray \& Schmid (1970) showed a reduction in the daily excretion of adrenaline and noradrenaline. Gordon et al. (1967) showed a reduction in renin production in one subject with 'autonomic deficiency' and went on to demonstrate that after an infusion of catecholamines his serum renin levels rose to almost normal values.

These studies suggest that there is an abnormality of sympathetic nervous function. Attempts have been made in various ways to compensate for this defective action, using elastic stockings, or even ' $G$ ' suit, steroids, and sympathomimetic presso agents.

In view of the role of noradrenaline as a neurotransmitter in the sympathetic nervous system monoamine oxidase inhibitors have been given in an attempt to potentiate the effects of the sympathetic nerves, but for reasons that are not known this is ineffective in postural hypotension. The logical extension of this therapy is to combine the effects of a monoamine oxidase inhibitor with a monoamine sympathomimetic agent. In the case reported here this therapy was resorted to and the results are discussed.

\section{Case history}

This 53-year-old man worked as a fitter and was first seen in June 1969 complaining of pain in the mid-lumbar spine and in both loins. In September 1969 he first developed symmetrical swelling of both ankles, which was most marked in the evening. The oedema became more marked and did not disappear in response to a small dose of bendrofluazide. His general health remained good but his appetite deteriorated and he developed slight constipation. His past medical history consisted of a peri-anal abscess which was incised at the age of 21 . The symptoms from the abscess only lasted about 2 weeks and there was no recurrence after drainage. He was admitted to Withington Hospital for further 
investigation in March 1970. At that time he was a fairly well-looking middle aged man. Weight $174 \mathrm{lb}$, supine blood pressure $110 / 60 \mathrm{mmHg}$, pulse $80 / \mathrm{min}$. The only abnormality at this time, on examination, was slight bilateral ankle oedema.

\section{Investigations}

Hb $15.9 \mathrm{~g} / 100 \mathrm{ml}$, WCC $7000 / \mathrm{mm}^{3}$, normal differential. ESR (Wintrobe) $40 \mathrm{~mm} / \mathrm{hr}$. Albumin $2.3 \mathrm{~g} / 100 \mathrm{ml}$, globulin $3.5 \mathrm{~g} / 100 \mathrm{ml}$, protein electrophoresis showed a slight rise in alpha 1 and alpha 2 globulin. Serum cholesterol $450 \mathrm{mg} / 100 \mathrm{ml}$. Blood urea $34 \mathrm{mg} / 100 \mathrm{ml}$. Serum sodium $140 \mathrm{mEq} / \mathrm{l}$, potassium $3.2 \mathrm{mEq} / \mathrm{l}$, chloride $94 \mathrm{mEq} / \mathrm{l}$. 24-hr urine analysis $1300 \mathrm{ml}$, sodium $42 \mathrm{mEq} / \mathrm{l}$, protein $6.9 \mathrm{~g} / 24 \mathrm{hr}$. There were no cells in the urine and it was sterile on culture. Anti-nuclear factor, LE cell test and the blood WR were all negative. 24-hr urinary ketogenic steroid output $14 \mathrm{mg}$. Urinary amino acid output within normal limits. 3-day faecal fat collection $7 \cdot 3 \mathrm{~g} / 24 \mathrm{hr}$. PBI $5 \mu \mathrm{g} / 100 \mathrm{ml}$. Glucose tolerance test normal. Radiology-chest X-ray normal, IVP-normal kidneys, ureters and bladder. Inferior venacavogram normal. Barium enema normal. Renal biopsy-amyloid material in the small blood vessels and one of the glomeruli.

\section{Progress}

He was treated with a diet containing $70 \mathrm{~g}$ of protein, $20 \mathrm{mEq}$ of sodium, and bendrofluazide $5 \mathrm{mg}$ twice daily. During his admission he complained of occasional dizziness on standing after he had lost $6 \mathrm{lb}$ in weight due to the diuretic. The bendrofluazide was reduced to $5 \mathrm{mg}$ on alternate days and his dizziness disappeared. However, when he was reviewed in June 1970 at a time when he had only lost $4 \mathrm{lb}$ in weight, he complained of troublesome dizziness on standing up. Examination revealed moderate ankle oedema, and BP $120 / 80 \mathrm{mmHg}$ lying and $75 \mathrm{~mm}$ systolic on standing. He became impotent and developed a reactive depression which improved considerably with amitriptyline. In July 1970 he had lost $7 \mathrm{lb}$ in weight and the oedema had disappeared, the dizziness was worse, the BP $95 / 75 \mathrm{mmHg}$ standing and 75/60 lying. For the first time he complained of angina of effort. In August 1970 his dizziness became very much worse during a period of hot weather. He vomited on a few occasions and was admitted to hospital and was found to have a BP of $60 / 40 \mathrm{mmHg}$ standing $35 /-$ lying. He was transfused with 21 of normal saline and $50 \mathrm{~g}$ of human salt-free albumin. This restored his BP on standing to $110 / 70 \mathrm{mmHg}$ and on lying to $70 / 45$ at the expense of considerable increase in his ankle oedema. For the first time he complained of slight dysphagia and huskiness of his voice, and a barium swallow was performed which was normal.
In September 1970 he was discharged wearing elastic stockings and an abdominal support, on $5 \mathrm{mg}$ of bendrofluazide a day and a $50 \mathrm{mEq}$ sodium diet. When seen in December 1970 he complained of attacks of severe dizziness that prevented him from walking more than a few yards and also of chronic diarrhoea. He was severely dehydrated, the BP was $110 / 70 \mathrm{mmHg}$ lying and was unmeasurable standing. $\mathrm{He}$ again responded to infusions of albumin and normal saline, and his diuretics were stopped. A ' $G$ ' suit was obtained which was fitted with a valve so that it could be inflated by a bicycle pump. The pressure suit pads were applied to the calves, the back of the thighs and the anterior abdominal wall. Table 1 shows the effect of the ' $G$ ' suit on the blood pressure. With the ' $G$ ' suit inflated he was able to walk without dizziness and with a reasonably maintained blood pressure. However, the continuous wearing of the suit was made difficult by recurrent attacks of watery diarrhoea as it could not be undone quickly in an emergency.

Hypotension became an increasing problem and on 25 February he was started on phenelzine, $15 \mathrm{mg}$ t.d.s. orally for 1 month. This had no beneficial effect on his blood pressure and when reviewed at the end of this month he had just had a further severe attack of diarrhoea and had a lying pressure of $90 / 60 \mathrm{mmHg}$ and no measurable BP in the standing position. He again responded well to saline and albumin infusions. He was re-admitted with further symptoms on 17 April. He now weighed $135 \mathrm{lb}$ and his BP was $55 \mathrm{mmHg}$ in the lying position and unmeasurable even sitting up. He had mild ankle oedema. His dysphagia was worse. A repeat barium swallow showed mild muscular inco-ordination of the oesophagus. The remaining general examination was normal. A series of pharmacological agents were tried in succession in an attempt to find one which would give sufficient pressure effect to maintain the blood pressure and prevent symptoms of postural hypotension. The results are shown in Table 2.

TABLE 1. The effect of a 'G' suit on the patient's postural hypotension. The inflatable pressure pads were applied to the calves, the back of the thighs, and to the anterior abdominal wall

\begin{tabular}{ccccc}
\hline & $\begin{array}{c}\text { Pressure in } \\
\text { the 'G' suit } \\
\text { pads }\end{array}$ & \multicolumn{2}{c}{} & \\
\cline { 3 - 4 } & Blood pressure (mmHg) & \\
\cline { 3 - 4 } & (mmHg) & Horizontal & Vertical & Comments \\
\hline No suit & - & $90 / 55$ & $75 / 45$ & Dizzy \\
'G' suit & 0 & $90 / 55$ & $65 / 40$ & Dizzy \\
& 50 & $95 / 60$ & $75 / 40$ & Dizzy \\
& 70 & $100 / 60$ & $77 / 50$ & Dizzy \\
& 100 & $85 / 60$ & $85 / 60$ & Not dizzy \\
& 130 & - & $95 / 60$ & Walks \\
& 150 & - & $100 / 60$ & Walks \\
\hline
\end{tabular}


Table 3 summarizes his clinical progress and Table 4 shows the corresponding laboratory data. In a final attempt to raise the blood pressure he was treated with tranylcypromine $30 \mathrm{mg}$ daily orally and simultaneously given vasopressors in the expectation of producing a controlled 'tyramine' crisis. We used tranylcypromine and, initially, tiny doses of ephedrine, noradrenaline, ethyl alcohol, ergotamine and leyodopa. Each drug was built up cautiously from very small to conventional doses. To our surprise only marginal increments of BP were obtained. The most promising combinations were tranylcypromine with levodopa, or with ephedrine. The former combination caused a rise of only $10 \mathrm{mmHg}$ and the latter of $30 \mathrm{mmHg}$ but with both combinations his BP was unmeasurable in the vertical position. Unfortunately, the best combination, tranylcypromine and levodopa caused intractable nausea and vomiting, attributed to the levodopa and had to be withdrawn. He was then put on a diet fortified with English Cheddar cheese $60 \mathrm{~g} 6$ hourly and Bovril four times daily. This too was totally unsuccess-

TABLE 2. Effects of pressor agents and other drugs on blood pressure

\begin{tabular}{|c|c|c|c|c|}
\hline \multirow[b]{2}{*}{ Drug } & \multicolumn{2}{|c|}{$\begin{array}{c}\text { Blood pressure } \\
\text { horizontal position } \\
(\mathrm{mmHg})\end{array}$} & \multicolumn{2}{|c|}{$\begin{array}{l}\text { Blood pressure } \\
\text { vertical position } \\
(\mathrm{mmHg})\end{array}$} \\
\hline & Before drug & After drug & Before drug & After drug \\
\hline $\begin{array}{l}\text { i.v. Mephentermine } \\
\text { i.v. Noradrenaline } \\
\text { Oral amphetamine } \\
\text { Oral Nardil } \\
\text { Oral Parnate }\end{array}$ & $\begin{array}{l}80 / 60 \\
85 / 55 \\
90 / 50 \\
90 / 60 \\
90 / 50\end{array}$ & $\begin{array}{l}145 / 85 \\
180 / 100 \\
100 / 70 \\
90 / 60 \\
90 / 60\end{array}$ & $\begin{array}{l}50 /- \\
50 /- \\
50 /- \\
50 /- \\
50 /-\end{array}$ & $\begin{aligned}< & 50 \\
& 85 / 60 \\
& 50 /- \\
< & 50 /- \\
< & 50 /-\end{aligned}$ \\
\hline
\end{tabular}

The patient was then treated with oral Parnate, and pressor agents were given simultaneously:

$\begin{array}{lrrrr}\text { Oral ephedrine } & 90 / 60 & 100 / 70 & 50 /- & 0 /- \\ \text { i.v. Noradrenaline } & 80 / 50 & 85 / 55 & 0 /- & 0 /- \\ \text { Oral brandy } & 60 / 40 & 80 / 60 & 0 /- & 0 /- \\ \text { Oral ergotamine } & 80 / 50 & 85 / 55 & 0 /- & 0 /- \\ \text { Oral levopopa } & 80 / 50 & 110 / 70 & 0 /- & 0 /-\end{array}$

Nardil, phenelzine dihydrogen sulphate; Parnate, tranylcypromine sulphate.

TABLE 3. A summary of the patient's progress

\begin{tabular}{|c|c|c|c|c|c|}
\hline \multirow[b]{2}{*}{ Date } & \multicolumn{2}{|c|}{$\begin{array}{l}\text { Blood pressure } \\
(\mathrm{mmHg})\end{array}$} & \multirow{2}{*}{$\begin{array}{l}\text { Sodium } \\
\text { intake } \\
\text { (mEq) }\end{array}$} & \multirow[b]{2}{*}{ Drugs } & \multirow{2}{*}{$\begin{array}{c}\text { Urea } \\
\text { clearance } \\
(\mathrm{ml} / \mathrm{min})\end{array}$} \\
\hline & Lying & Standing & & & \\
\hline $\begin{array}{l}\text { March } 1970 \\
\text { March } 1970\end{array}$ & $\begin{array}{l}110 / 60 \\
110 / 60\end{array}$ & $\begin{array}{c}90 / 50 \\
0\end{array}$ & $\begin{array}{l}\text { Normal } \\
20\end{array}$ & $\begin{array}{c}\text { Bendrofluazide (BF) } \\
10 \mathrm{mg} / \text { day }\end{array}$ & $\begin{array}{l}23 \cdot 0 \\
23 \cdot 0\end{array}$ \\
\hline $\begin{array}{l}\text { July } 1970 \\
\text { Dec. } 1970 \\
\text { March } 1971\end{array}$ & $\begin{array}{r}95 / 75 \\
110 / 70 \\
90 / 60\end{array}$ & $\begin{array}{c}75 / 60 \\
70 /- \\
50-70 /-\end{array}$ & $\begin{array}{l}20 \\
50 \\
50\end{array}$ & $\begin{array}{c}\text { BF } 5 \mathrm{mg} / \text { day } \\
\text { nil } \\
\text { Nardil } \\
45 \mathrm{mg} / \text { day }\end{array}$ & \\
\hline $\begin{array}{l}\text { April } 1971 \\
\text { May } 1971 \\
\text { June } 1971\end{array}$ & $\begin{array}{l}55 /- \\
85 / 60 \\
70 / 50\end{array}$ & $\begin{array}{c}40-50 /- \\
40-50 /- \\
50\end{array}$ & $\begin{array}{l}50 \\
50 \\
50\end{array}$ & $\begin{array}{c}\text { Parnate } \\
\text { and cheese }\end{array}$ & $2 \cdot 0$ \\
\hline
\end{tabular}

TABLE 4. Sequential changes in haemoglobin and renal function during the course of the patient's illness

\begin{tabular}{|c|c|c|c|c|c|c|c|}
\hline \multirow[b]{2}{*}{ Date } & \multirow[b]{2}{*}{$\begin{array}{c}\mathrm{Hb} \\
(\mathrm{gm} / 100 \mathrm{ml})\end{array}$} & \multirow[b]{2}{*}{$\begin{array}{l}\text { Blood urea } \\
(\mathrm{mg} / 100 \mathrm{ml})\end{array}$} & \multirow{2}{*}{$\begin{array}{c}\text { Serum } \\
\text { albumen } \\
(\mathrm{g} / 100 \mathrm{ml})\end{array}$} & \multicolumn{2}{|c|}{ Urine 24-hr output } & \multirow{2}{*}{$\begin{array}{c}\text { Urea } \\
\text { clearance } \\
\text { (ml/min) }\end{array}$} & \multirow{2}{*}{$\begin{array}{c}\text { 17-Ketogenic } \\
\text { steroid } \\
(\mathrm{mg} / 24 \mathrm{hr})\end{array}$} \\
\hline & & & & $\begin{array}{l}\text { Sodium } \\
(\mathrm{mEq})\end{array}$ & $\begin{array}{l}\text { Protein } \\
\text { (g) }\end{array}$ & & \\
\hline March 1970 & 110 & 19 & $2 \cdot 3$ & 40 & $7 \cdot 0$ & $23 \cdot 0$ & - \\
\hline Sept. 1970 & 70 & 37 & $2 \cdot 5$ & 96 & $7 \cdot 0$ & $20 \cdot 0$ & - \\
\hline Oct. 1970 & - & 40 & 1.9 & 100 & $6 \cdot 6$ & $12 \cdot 0$ & - \\
\hline April 1971 & 66 & 103 & $2 \cdot 3$ & 100 & $8 \cdot 6$ & - & 10 \\
\hline June 1971 & 44 & 126 & $3 \cdot 0$ & 100 & $10 \cdot 4$ & $2 \cdot 0$ & 14 \\
\hline
\end{tabular}


ful. In the meantime his general condition had been deteriorating, with intractable faintness accompanied by an unrecordable blood pressure even in the lying position and he died in uraemic coma.

\section{Necropsy}

Heart $560 \mathrm{~g}$, mild left ventricular hypertrophy, some small areas of grey tissue throughout the myocardium, no evidence of myocardial infarction. Slight non-occlusive atheromatous disease in the coronary vessels. Oedema in both lung bases.

The kidneys weighed $150 \mathrm{~g} \mathrm{R}$, and L. Slight lobulation of the left kidney; blurring of the corticomedullary junction.

Histology: amyloid material was almost universally found. It was prominent in the blood vessels of every organ. It was infiltrated between the muscle fibres of the heart, the oesophagus, tongue and skeletal muscle. It was seen in the submucosa of the oesophagus, ileum, and colon; in pancreatic nerves and vessels, and replacing some acini; in splenic malphighian corpuscles; in the walls of the hepatic bile ducts; in lymph node sinuses; between collagen fibres in the dermis.

The kidneys had amyloid in the glomeruli and the basement membrane of the tubules. There was also some interstitial infiltration with polymorphs and lymphocytes and occasional sclerosed glomeruli. The vessels were also affected.

Nervous tissue: The brain and spinal cord were normal. The posterior root ganglia were normal, except that there was amyloid in the small blood vessels; no obvious neuronal fallout. Sections of proximal spinal nerves normal, but amyloid in the vessels. In the sympathetic ganglia there was considerable amyloid in the vessels, and in the interstitial tissue; there appeared to be some degenerative change in occasional ganglion cells. Amyloid was present amongst the fibres of the autonomic plexuses of the pancreas, the bladder, the ileum, and the colon.

\section{Discussion}

Various therapeutic manoeuvres have been utilized in postural hypotension and some of the more prominent are mentioned hereafter. The use of a combination of salt supplementation in the diet and oral fludrocortisone has been used in an attempt to increase the total plasma and extracellular fluid volume. This, of course, was irrelevant to our patient who, although hypotensive, was usually moderately oedematous and therefore presumably salt-overloaded. Plasma expanders have been used for the purpose of raising a depleted plasma volume in such a manner that the increment will remain in the vascular compartment. This was the only therapy which in our patient produced a regular increase in blood pressure with considerable control of postural hypotension, but at a late stage in the development of his illness, he had severe postural hypotension even when his plasma proteins were only just below the lower limit of normal, and it might be presumed that his plasma volume was likewise only just below normal.

In this situation it was presumed that hypotension in the presence of a normal plasma volume is due to a failure in increase of tone of the capacity vessels of the circulation of the lower half of the body, in particular large veins in the legs and lower abdomen. Attempts to mechanically diminish the ability of these reservoirs to expand was made by applying elastic stockings and an abdominal binder with little success. However, the application of a ' $G$ ' suit with pressure pads over the major muscle bulk of the lower limbs and abdomen did lead to a very considerable improvement of his symptoms for some time. It was unfortunate that he was unable to continue to wear it. Various pharmacological agents were used here and the results are shown in Table 2. It is obvious that whereas several pressor agents caused an elevation in the blood pressure in the horizontal position, no benefit was obtained when he stood upright with any agent at all. The fact that some rise in the BP was produced in the horizontal suggests that some resistance vessels are able to vasoconstrict, and the postural hypotension raises the possibility that perhaps there was a greater failure of vasoconstriction in the capacity vessels, i.e. (veins) than in the arterioles.

The absence of tachycardia in the vertical position is itself a manifestation of deficient function in the autonomic baroreceptor reflex arcs and contributed to the postural hypotension. This mechanism would be responsible for fainting whilst defaecating and whilst performing a Valsalva manoeuvre.

It was felt that the most probable cause of the postural hypotension was failure of the sympathetic efferent activity due to amyloid neuropathy. We hoped to potentiate the action of the sympathetic efferent activity by the use of a monoamine oxidase inhibitor. Neither tranylcypromine nor phenelzine was effective. It is suspected that this was due to structural damage sustained by the nerves and arterioles. The results of this therapy were disappointing. Seller (1969) treated a 49-year-old negro with incapacitating PHT which had failed to respond to conventional therapy with tranylcypromine $10 \mathrm{mg}$ t.d.s. and hydroxyamphetamine $20 \mathrm{mg} 2$ hourly from 6 a.m. to 6 p.m. Before treatment this patient's standing BP was $30 \mathrm{mmHg}$ and on the treatment it rose to $110 \mathrm{mmHg}$. He was able to lead a fairly normal life afterwards on treatment and until the time of writing 14 months later. Diamond et al. (1970) treated a similar patient with tranylcy- 
promine $60 \mathrm{mg} /$ day and New York State Cheddar cheese $60-90 \mathrm{~g}$ daily. This patient had been unable to sit up for more than $30 \mathrm{sec}$. On treatment he could sit up for $6 \mathrm{hr}$ daily and stand for short periods. Finally one ought to mention the report of Hunter et al. (1970) who took a normotensive patient, established on a steady dose of phenelzine $45 \mathrm{mg} / \mathrm{d}$ for 10 days, and administered one $50 \mathrm{mg}$ dose of levodopa orally. The BP rose from 130/90 to $200 / 130 \mathrm{mmHg}$ in $1 \mathrm{hr}$ when the procedure was stopped and treatment with $9 \mathrm{mg}$ of phenoxybezamine restored the BP to normal.

\section{Conclusions}

Our patient had no compensatory vasoconstriction to combat postural hypotension. Pharmacological studies suggest that significant vasoconstriction can be produced by agents acting on the vessels directly. His postural hypotension therefore suggests that the lesion lies proximally and it is suggested that the amyloid deposits in the ganglia and/or peripheral nerves may be responsible for insufficient sympathetic efferent effect. This lesion is similar in site to lesions inferred by physiological studies by Bannister in the analogous situation of idiopathic postural hypotension, and suspected as a result of biochemical studies, and of anatomical studies showing cellular fallout in the central connections of the autonomic nervous system.

\section{References}

Bannister, R., Ardill, L. \& Fenton, P. (1967) Defective autonomic control of blood vessels in idiopathic ortho- $\frac{Q}{C}$ static hypotension. Brain, 90, 725.

Diamond, M.A., Murray, R.H. \& Schmid, P.G. (1970) Idiopathic postural hypotension. Physiologic observation $\overline{0}$ and report of a new mode of therapy. Journal of Clinical $\bar{\square}$ Investigation, 49, 1341.

Gordon, R.D., Kuchell, O., Liddle, G.W. \& Island, D.P. $\overrightarrow{\widehat{D}}$ (1967) Role of the sympathetic nervous system in regulat- $Q$ ing renin and aldosterone production. Journal of Clinical Investigation, 46, 599.

Hunter, K.R., Boakes, A.J., Laurence, D.R. \& Stern, ? G.M. (1970) Monoamine oxidase inhibitors and levodopa. $\vec{\omega}$ British Medical Journal, 3, 388.

Kyle, R.A., KottKe, B.A. \& Schirger, A. (1966) Orthostatic hypotension as a clue to primary systemic amyloid. 3 Circulation, 34, 883.

LUFT, R. \& voN EULER, UlF.S. (1955) Diminished excretion iv of norepinephrine and epinephrine in two cases of orthostatic postural hypotension. Journal of Clinical Investi- ir gation, 32, 1065.

McC. Goodall, Harlan, W.R. \& Alton, H. (1968) 을 Decreased noradrenaline synthesis in neurogenic ortho- static hypotension. Circulation, 38, 592.

Munsat, T.L. \& Poussaint, A.F. (1962) Clinical manifestations and diagnosis of amyloid polyneuropathy. 를 Neurology, 12, 413.

SELler, R.H. (1969) Idiopathic orthostatic hypotensio o Report of successful treatment with a new form of therap American Journal of Cardiology, 23, 838.

\title{
Carcinoma of the pancreas and hyperosmolar coma
}

\author{
ANDREW G. CUDWORTH \\ M.B., M.R.C.P. (U.K.) \\ David Lewis Northern Hospital, Liverpool
}

\begin{abstract}
Summary
A case of hyperosmolar coma with carcinoma of the pancreas is reported. There appears to be no previous report of this association.
\end{abstract}

THE association of carcinoma of the pancreas with late onset 'brittle' diabetes is well recorded, but there appears to be no previous report of carcinoma of the pancreas presenting as a non-ketotic diabetic coma.

\section{Case report}

The patient, a white male, aged 76 years was admitted in an unconscious state, responding only to painful stimuli. Four days earlier he had presented to his general practitioner with a 5 weeks' history of general malaise, weakness, epigastric discomfort and loss of appetite. His wife noted that recently he had taken only soups, but during the week prior to admission he had stopped eating altogether, and over the preceding 2 days had progressively drifted into a state of unconsciousness. There were no previous illnesses of note, and no family history of diabetes mellitus.

On examination he was of lean build with signs of marked dehydration. He was afebrile with a normal pulse, blood pressure and quiet respiration. There was a striking increase in tone in all four limbs, neck rigidity and conjugate deviation of the 